\title{
Sudorese Profusa e Hipotermia após Administração de Morfina por Via Subaracnóidea. Relato de Caso *
}

\section{Excessive Sweating and Hypothermia after Spinal Morphine. Case Report}

Gustavo Prosperi Bicalho, TSA ${ }^{1}$; Carlos Henrique Viana Castro, TSA ${ }^{1}$; Marcos Guilherme Cunha Cruvinel, TSA ${ }^{1}$; Roberto Cardoso Bessa Júnior, TSA ${ }^{1}$

\begin{abstract}
RESUMO
Bicalho GP, Castro CHV, Cruvinel MGC, Bessa Júnior RC - Sudorese Profusa e Hipotermia após Administração de Morfina por Via Subaracnóidea. Relato de Caso
\end{abstract}

JUSTIFICATIVA E OBJETIVOS: A anestesia e a cirurgia freqüentemente causam perturbações térmicas significativas. A hipotermia durante a anestesia é o distúrbio térmico peri-operatório mais comum. O presente relato evidenciou um mecanismo não usual de alteração do controle térmico corporal, neste caso, associado à utilização da morfina no espaço incomum.

RELATO DO CASO: Paciente do sexo feminino, 44 anos, estado físico ASA I, sem doenças prévias conhecidas, foi admitida para histerectomia abdominal por quadro de miomatose uterina. Foi realizada raquianestesia com $20 \mathrm{mg}$ de bupivacaína hiperbárica e $100 \mu \mathrm{g}$ de morfina. Durante o procedimento não apresentou qualquer intercorrência. Na sala de recuperação pós-anestésica (SRPA), 3h30 minutos após a realização do bloqueio, a paciente apresentou quadro de sudorese profusa do tronco levando, inclusive, ao descolamento de eletrodos e de fitas adesivas, leve sonolência minutos subseqüentes manteve temperatura abaixo de $36^{\circ} \mathrm{Ce}$ com 90 minutos após o evento já apresentava temperatura de $36,2^{\circ} \mathrm{C}$ e remissão completa dos sintomas.

CONCLUSÕES: Além dos clássicos mecanismos de perda excessiva de calor durante o bloqueio do neuro-eixo, podem ocorrer perturbações diretas nos centros hipotalâmicos de controle da temperatura corporal, neste caso, associado ao uso de morfina por via subaracnóidea.

Unitermos: TÉCNICAS ANESTÉSICAS, Regional: subaracnóidea; COMPLICAÇÕES: hipotermia

\footnotetext{
* Recebido do (Received from) Departamento de Anestesiologia do Hospital Life Center, Belo Horizonte, MG
}

1. Anestesiologista do Hospital Life Center

Apresentado (Submitted) em 27 de janeiro de 2005

Aceito (Accepted) para publicação em 14 de dezembro de 2005

Endereço para correspondência (Correspondence to)

Dr. Gustavo Prosperi Bicalho

Rua Alvarenga Peixoto, 711/1301

30180-120 Belo Horizonte, MG

(c) Sociedade Brasileira de Anestesiologia, 2006 subaracnóideo. O objetivo deste relato foi descrever este efeito e diminuição da temperatura timpânica para $35,2^{\circ} \mathrm{C}$. Nos 60

E-mail: gpbicalho@terra.com.br

\section{SUMMARY}

Bicalho GP, Castro CHV, Cruvinel MGC, Bessa Júnior RC Excessive Sweating and Hypothermia after Spinal Morphine. Case Report

BACKGROUND AND OBJECTIVES: Anesthesia and surgery often promote significant temperature changes. Hypothermia during anesthesia is the most common perioperative thermal disorder. This report describes an unusual body heat balance change associated to spinal morphine.

CASE REPORT: Female patient, 44 years old, physical status ASA I, with no previous diseases, admitted for abdominal hysterectomy due to uterine myomatosis. Spinal anesthesia was performed with $20 \mathrm{mg}$ hyperbaric bupivacaine and $100 \mu \mathrm{g}$ morphine and surgical procedure was eventless. In the post-anesthetic recovery unit (PACU), 3 h30 minutes after blockade, patient presented excessive sweating, even leading to detachment of electrodes and adhesive tapes, mild sleepiness and decreased tympanic temperature to $35.2^{\circ} \mathrm{C}$. Temperature was maintained below $36^{\circ} \mathrm{C}$ for the next 60 minutes and 90 minutes later temperature was $36.2^{\circ} \mathrm{C}$ with total remission of symptoms. CONCLUSIONS: In addition to classic excessive heat loss mechanisms during neuraxial block, there may be direct disorders in the hypothalamic temperature control centers, in this case associated to spinal morphine.

Key Words: ANESTHETIC TECHNIQUES, Regional: spinal block; COMPLICATIONS: hypothermia

\section{INTRODUÇÃO}

A hipotermia durante a anestesia é o distúrbio térmico Aperi-operatório mais comum ${ }^{1}$. Ela resulta de uma combinação de alterações da termorregulação induzida pela anestesia, exposição ao ambiente frio e a fatores cirúrgicos que levam à perda excessiva de calor ${ }^{1}$. Nos bloqueios de neuro-eixo as perturbações térmicas podem ser iguais ou até maiores que aquelas observadas durante a anestesia geral ${ }^{1}$. O presente relato evidenciou um mecanismo não usual de alteração do controle térmico corporal, neste caso, associado à utilização da morfina no espaço subaracnóideo. O objetivo deste relato foi descrever este efeito incomum associado à administração de morfina por via subaracnóidea.

\section{RELATO DO CASO}

Paciente do sexo feminino, 44 anos, $56 \mathrm{~kg}, 1,62 \mathrm{~m}$, estado físico ASA I, foi admitida para realização de histerectomia abdominal, devido a quadro de miomatose uterina. $\mathrm{Na}$ sala de cirurgia foi monitorizada com ECG, oxímetro de pulso, pressão arterial não-invasiva e realizada venóclise 
com cateter 18G. A raquianestesia foi realizada com a paciente na posição sentada em $L_{2}$ - $L_{3}$, com agulha de Withacre 27G. Injetados $20 \mathrm{mg}$ de bupivacaína hiperbárica associada a $100 \mu \mathrm{g}$ de morfina, obtendo-se bloqueio sensitivo em $\mathrm{T}_{6}$. Como sedação associada ao bloqueio, administrou-se midazolam em doses fracionadas (total $15 \mathrm{mg}$ ), droperidol $(1,25$ $\mathrm{mg})$ e fentanil $(25 \mu \mathrm{g})$. Recebeu como profilaxia antiemética $10 \mathrm{mg}$ de dexametasona no início do procedimento e $4 \mathrm{mg}$ de ondansetron, ao final. $\mathrm{O}$ ato cirúrgico não apresentou intercorrências, com duração de 90 minutos. Durante o procedimento a paciente recebeu $2500 \mathrm{~mL}$ de Ringer com lactato pré-aquecido. O pré-aquecimento é realizado em dispositivo de microondas obtendo-se soluções cristalóides com temperatura de aproximadamente $37^{\circ} \mathrm{C}$. A temperatura da sala de cirurgia é mantida por ar condicionado central, cujo acionamento mantém a temperatura da sala em aproximadamente $22^{\circ} \mathrm{C}$. A paciente recebeu isolamento térmico com cobertores em toda a região do tórax e membros superiores. Ao final do procedimento foi encaminhada a SRPA e mantida a monitorização utilizada durante a cirurgia.

À admissão na SRPA apresentava dados hemodinâmicos e ventilatórios estáveis e temperatura axilar de $35,9^{\circ} \mathrm{C}$.

Após duas horas da admissão na SRPA (3h30 minutos após a realização do bloqueio) a paciente apresentou quadro de sudorese profusa de todo o tronco, segmento cefálico e membros superiores levando, inclusive, ao descolamento de eletrodose de fitas adesivas. Associadas à sudorese, apresentava leve sonolência e diminuição da temperatura axilar para $35,2^{\circ} \mathrm{C}$ (mesmo valor obtido para a temperatura timpânica). Neste momento já não apresentava bloqueio motor nos membros inferiores. Inicialmente foram trocados todos os dispositivos para acesso venoso (cateter, equipo e bolsa de soro) considerando-se possível reação pirogênica, que posteriormente não se confirmou, pois a paciente manteve-se hipotérmica. Foi medida glicemia capilar, que se encontrava em níveis normais, excluindo-se eventual crise hipoglicêmica.

Não apresentava qualquer alteração dos dados vitais durante o episódio, a não ser a alteração da temperatura. Nos 60 minutos subseqüentes manteve temperatura abaixo de $36{ }^{\circ} \mathrm{C}$ ainda associada à intensa sudorese e com 90 minutos após o evento já apresentava temperatura axilar de $36,2^{\circ} \mathrm{Ce}$ remissão completa dos sintomas.

\section{DISCUSSÃO}

A anestesia e a cirurgia freqüentemente causam perturbações térmicas significativas. Ahipotermia é o fenômeno mais comum e resulta do efeito dos anestésicos sobre o controle termorregulatório corporal, freqüentemente associado à exposição ao ambiente frio e a fatores cirúrgicos que levam a perda excessiva de calor ${ }^{1}$.

De uma forma geral, entende-se o controle térmico corporal como um sistema de três fases, sendo uma aferente, uma central e outra eferente. A integração destas três fases faz com que a temperatura central seja mantida em níveis bastante estritos ${ }^{2}$.
A fase aferente corresponde aos receptores térmicos presentes na pele, tecidos profundos, medula e encéfalo. Estes receptores enviam sinais que em última análise são integrados no hipotálamo, especialmente na região anterior pré-óptica. Quando a integração destes sinais no hipotálamo mostra um desvio de um nível estrito de temperatura, o hipotálamo gera uma resposta termorregulatória visando uma redução ou aumento da perda de calor corpóreo para o ambiente obtendo-se, desta forma, novamente o equilíbrio. Nas situações em que ocorre um desvio para baixo da temperatura central, o hipotálamo gera respostas para a conservação do calor, sendo que as respostas principais são inicialmente a vasoconstrição periférica e posteriormente os tremores musculares. Por outro lado, quando a temperatura é desviada para um nível superior, o hipotálamo gera uma resposta para aumentar a perda de calor, inicialmente ocorre a vasodilatação periférica e posteriormente a sudorese. A sudorese é um mecanismo bastante efetivo e que pode aumentar em até 10 vezes a perda de calor corpóreo. O intervalo de temperatura entre estas duas respostas é chamado de faixa interlimiar e geralmente é de apenas $0,2^{\circ} \mathrm{C}^{2}$. Sabe-se que, na realidade, a integração destas informações térmicas é bastante complexa envolvendo vias polisinápticas com participação da formação reticular ascendente, locus sub-ceruleus, núcleo magno da rafe, entre outros. Entretanto, a maioria dos investigadores aceita que a região pré-óptica do hipotálamo anterior é o centro termorregulatório dominante em mamífe$\operatorname{ros}^{3-6}$.

Sabe-se que a faixa interlimiar é bastante aumentada durante a anestesia assim como as respostas para conservação ou geração de calor são atenuadas. Desta forma, o paciente, quando anestesiado, torna-se muito mais vulnerável a alterações da temperatura central.

Sabe-se que os pacientes submetidos aos bloqueios do neuro-eixo também estão sob risco de desenvolver hipotermia intra-operatória, com reduções da temperatura central, similares àquelas observadas durante a anestesia geral ${ }^{3}$. Entretanto, os mecanismos no desenvolvimento da hipotermia exibem algumas diferenças.

Nos bloqueios do neuro-eixo três são os principais mecanismos responsáveis pela diminuição da temperatura central corporal. O primeiro é a redistribuição de calor ocasionado pela simpatectomia e vasodilatação no território anestesiado transferindo calor do compartimento central para o periférico, sendo este o principal mecanismo que ocorre na primeira hora após o bloqueio. Esta redistribuição inicial pode causar diminuição de 1 a $2{ }^{\circ} \mathrm{C}$ na temperatura central. Em segundo lugar tem-se a perda da vasoconstrição termorregulatória nos territórios anestesiados diminuindo bastante a eficácia da conservação de calor. E por fim tem-se uma redução do limiar de vasoconstrição e de tremores no paciente com bloqueio do neuro-eixo, mesmo em regiões não anestesiadas ${ }^{1}$. Na paciente em questão foi observado que à admissão na SRPA, apresentava temperatura axilar de $35,9^{\circ} \mathrm{C}$. Após a admissão na SRPA esperava-se uma significativa redução da perda de calor corporal em relação ao período da cirurgia devido a alguns fatores. Primeiro a temperatura ambiente 
em relação à sala de cirurgia é maior, visto que não é permitido o uso do ar condicionado neste setor obtendo-se temperaturas entre 24 a $26^{\circ} \mathrm{C}$. A paciente recebeu um isolamento térmico mais adequado devido ao uso de cobertores na quase totalidade da área corpórea. E por fim já não havia perda térmica pela área cirúrgica. A diminuição da temperatura ocorreu duas horas após a admissão na SRPA, em uma fase que não se espera uma diminuição adicional da temperatura pelos motivos já descritos.

Porém o fenômeno que indica uma provável perturbação da resposta termorregulatória fisiológica é a associação com uma resposta autonômica não esperada. Configurou-se uma situação em que a paciente com quadro de hipotermia leve (temperatura axilar de $35,2^{\circ} \mathrm{C}$ ) exibia uma profusa sudorese nos segmentos não bloqueados. Conforme mencionada, a sudorese é um mecanismo que opera o limite superior da faixa interlimiar, um limite que desencadeia perda de calor em uma situação onde a temperatura central está se elevando.

Os opióides reconhecidamente interferem na termorregulação corporal. O efeito característico é uma redução do limiar de vasoconstrição e alteração do limiar para tremores musculares $^{6}$. Com freqüência, na prática clínica, são administrados com intuito de inibir os tremores musculares causados por hipotermia pós-operatória, justamente pelo fato de alterarem seu limiar para esta resposta. Este efeito está presente em todos os agonistas $\mu$. Cabe ressaltar, que com relação a este efeito, a meperidina é mais eficaz quando comparada a outros opióides em doses equi-analgésicas, pois exibe uma alteração mais pronunciada do limiar de tremores musculares ${ }^{6}$. Considera-se que esta maior eficácia possa ser devida a um efeito mediado por receptores $\kappa$. Entretanto, no caso descrito, estes efeitos clássicos dos opióides não correspondem ao fenômeno observado, ou seja, uma profusa sudorese em uma paciente com hipotermia leve.

O fenômeno observado já foi relatado por outros autores. Sayyid e col. relataram caso de hipotermia até $33,6^{\circ} \mathrm{C}$ associada à sudorese intensa em uma gestante que recebeu 100 $\mu \mathrm{g}$ de morfina subaracnóidea para analgesia pós-operatória ${ }^{4}$. O início dos sintomas ocorreu três horas após a realização do bloqueio. Após duas horas do início dos sintomas a paciente recebeu $400 \mu \mathrm{g}$ de naloxona, com rápida reversão do quadro e aumento da temperatura.

Wishaw também relata um caso de hipotermia (temperatura timpânica de $33,6^{\circ} \mathrm{C}$ ) associada à administração de morfina subaracnóidea em uma parturiente submetida à cesariana sob raquianestesia ${ }^{5}$.

Pode-se considerar que no caso em questão a morfina aplicada no neuro-eixo, por dispersão cefálica, alcançou receptores opióides na região hipotalâmica após um período de aproximadamente $3 \mathrm{~h} 30$ minutos. Foi, então, gerada uma perturbação do centro termorregulatório com uma provável definição de um novo ponto de equilíbrio hipotalâmico de temperatura, ou seja, a faixa interlimiar como um todo foi deslocado para um nível inferior. Desta forma, a temperatura central encontrava-se acima deste novo limiar superior de temperatura, gerando uma resposta intensa, a sudorese, com conseqüente perda de calor para o ambiente e hipoter- mia. Esta resposta só ocorreu nas regiões acima da linha umbilical, pois os segmentos mais distais ainda estavam sob efeito do bloqueio simpático residual.

O presente relato evidenciou que as interações entre fatores anestésicos, cirúrgicos e do meio ambiente, no desenvolvimento das perturbações térmicas intra-operatórias podem ser ainda mais complexas. Além dos clássicos mecanismos de perda excessiva de calor durante o bloqueio do neuro-eixo, podem ocorrer perturbações diretas nos centros hipotalâmicos de controle da temperatura corporal, no presente caso, associado ao uso de morfina por via subaracnóidea.

\section{Excessive Sweating and Hypothermia after Spinal Morphine. Case Report}

Gustavo Prosperi Bicalho, TSA, M.D.; Carlos Henrique Viana Castro, TSA, M.D.; Marcos Guilherme da Cunha Cruvinel, TSA, M.D.; Roberto Cardoso Bessa Júnior, TSA, M.D.

\section{INTRODUCTION}

Hypothermia during anesthesia is the most common perioperative thermal disorder ${ }^{1}$. It results from the combination of anesthesia-induced thermoregulation changes, and exposure to cold environment and surgical factors which lead to excessive heat loss ${ }^{1}$. Thermal disorders during neuraxial block may be equal or even more severe than those observed during general anesthesia ${ }^{1}$. This report describes an unusual body heat balance change associated to spinal morphine.

\section{CASE REPORT}

Female patient, 44 years old, physical status ASAI, admitted for abdominal hysterectomy due to uterine myomatosis. Monitoring in the operating room consisted of ECG, pulse oximetry, noninvasive blood pressure and venous access with $18 \mathrm{G}$ catheter. Spinal anesthesia was performed with patient in the sitting position in $L_{2}-L_{3}$ interspace, with $27 G$ Withacre needle. Sensory block at $T_{6}$ was obtained with 20 $\mathrm{mg}$ hyperbaric bupivacaine associated to $100 \mu \mathrm{g}$ morphine. Patient was sedated with fractional midazolam doses (total $15 \mathrm{mg}$ ), droperidol (1.25 mg) and fentanyl $(25 \mu \mathrm{g})$.

Patient received $10 \mathrm{mg}$ dexametasone at surgery beginning and $4 \mathrm{mg}$ ondansetron at surgery completion to prevent nausea and vomiting. During the procedure patient received $2500 \mathrm{~mL}$ pre-heated lactated Ringer's. Solution is pre-heated in a microwave device resulting in crystalloid solutions of approximately $37^{\circ} \mathrm{C}$. Operating room temperature is maintained by central air conditioning system, which maintains temperature in approximately $22^{\circ} \mathrm{C}$. Patient was thermally isolated with blankets on chest and upper limbs. At the Vol. 56, No 1, Janeiro - Fevereiro, 2006 
end of the surgery patient was referred to the PACU and perioperative monitoring was maintained.

At PACU admission, patient presented stable hemodynamic and ventilatory parameters and axillary temperature of $35.9^{\circ} \mathrm{C}$.

Two hours after PACU admission (3h30 minutes after blockade), patient presented excessive body, head and arms sweating, even leading to detachment of electrodes and adhesive tapes, in addition to mild sleepiness and decreased axillary temperature to $35.2^{\circ} \mathrm{C}$ (equal to tympanic temperature). Initially, all venous access devices (catheter, device and serum bag) were replaced considering a possible pyrogenic reaction which was not confirmed because patient remained with low temperature. Capillary glycemia was within normal levels thus excluding the possibility of hypoglycemia.

No changes in vital signs, except for temperature, were observed during the episode. Temperature was maintained below $36^{\circ} \mathrm{C}$ for the next 60 minutes, still associated to excessive sweating, and 90 minutes later axillary temperature was $36.2^{\circ} \mathrm{C}$ with total remission of symptoms.

\section{DISCUSSION}

Anesthesia and surgery often promotes significant thermal disorders. Hypothermia is the most common phenomenon and results from anesthetic effects on body thermoregulatory control, usually associated to exposure to cold environment and to surgical factors leading to excessive heat loss ${ }^{1}$.

In general, body heat balance is a three-stage system: one afferent, one central and one efferent. The integration of these three stages maintains core temperature within very narrow levels ${ }^{2}$.

The afferent stage corresponds to skin, deep tissues, spinal cord and brain thermal receptors. These receptors send signals which ultimately are integrated in the hypothalamus, especially in the anterior pre-optic region. When the integration of such signals in the hypothalamus shows a deviation from a temperature level, the hypothalamus generates a thermoregulatory response aiming at increasing or decreasing body heat loss to the environment, thus returning to balance.

When there is core temperature down-deviation, the hypothalamus generates responses to maintain heat and major responses are initially peripheral vasoconstriction and then muscle shivering. On the other hand, when there is temperature up-deviation, the hypothalamus generates a response to increase heat loss and may increase in up to 10 times body heat loss. Temperature interval between these two responses is called inter-threshold range and in general is just $0.2^{\circ} \mathrm{C}^{2}$. In fact, it is known that the integration of thermal information is highly complex involving polysynaptic pathways with the participation of ascending reticular formation, locus sub-ceruleus and raphe nucleus magnum, among others. However, most investigators accept that the hypothalamus pre-optic region is the dominant thermoregulatory center in mammalians ${ }^{3-6}$.
It is known that the inter-threshold range is highly increased during anesthesia, as well as responses to maintain or generate heat are decreased. This way, anesthetized patients are much more vulnerable to core temperature changes.

It is known that patients submitted to neuraxial block are at risk of developing intraoperative hypothermia, with core temperature decreases similar to those observed during general anesthesia ${ }^{3}$. However, hypothermia mechanisms are somewhat different.

During neuraxial blocks, there are three primary mechanisms in charge of decreasing core temperature. The first is heat redistribution by sympathectomy and vasodilation of the anesthetized territory, transferring heat from core to peripheral compartment, being it the primary mechanism seen in the first post-blockade hour. This initial redistribution may decrease core temperature in 1 to $2^{\circ} \mathrm{C}$. Then, there is thermoregulatory vasoconstriction loss in anesthetized territories decreasing a lot the efficacy of heat maintenance. Finally, there is a decrease of vasoconstriction and shivering thresholds in patients with neuraxial block even in non-anesthetized regions ${ }^{1}$.

At PACU admission, our patient presented axillary temperature of $35.9^{\circ} \mathrm{C}$. A significant heat loss decrease was expected after PACU admission as compared to the intraoperative period, due to some factors. First, room temperature is higher as compared to the operating room since air temperature in this sector where between 24 and $26^{\circ} \mathrm{C}$. Patient received a better thermal isolation with blankets covering almost all her body. And finally, there was no longer heat loss by the surgical area. Temperature decreased two hours after PACU admission when additional temperature decrease is no longer expected due to above-mentioned reasons.

However, the phenomenon indicating a possible physiological thermoregulatory response disorder is the association with an unexpected autonomic response. The situation was a patient with mild hypothermia (axillary temperature of $35.2^{\circ} \mathrm{C}$ ) and excessive sweating in unblocked segments. As mentioned, sweating is a mechanism operating in the upper limit of the inter-threshold range, a limit which triggers heat loss in a situation where core temperature is increasing. It is known that opioids interfere with body thermoregulation. The typical effect is a decrease in vasoconstriction and a change in muscle shivering thresholds ${ }^{6}$. They are usually administered in the clinical practice to inhibit muscle shivering caused by postoperative hypothermia exactly because they modify its threshold. This effect is present in all $\mu$ agonists. It has to be stressed with regard to this effect that meperidine is more effective as compared to other opioids in equipotent doses for more markedly decreasing muscle shivering ${ }^{6}$. This higher efficacy may be due to $\kappa$ receptors-mediated effects. However, in our case, these classic opioid effects did not correspond to the observed phenomenon, that is, excessive sweating in a mildly hypothermal patient.

This phenomenon has already been reported by other authors. Sayyid et al. have reported a case of hypothermia of $33.6^{\circ} \mathrm{C}$ associated to excessive sweating in a pregnant patient receiving $100 \mu \mathrm{g}$ spinal morphine for postoperative anal- 
gesia ${ }^{4}$. Symptoms started three hours after blockade. Two hours later patient received $400 \mu \mathrm{g}$ naloxone with prompt reversion of symptoms and increased temperature.

Wishaw also reports a case of hypothermia (tympanic temperature of $33.6^{\circ} \mathrm{C}$ ) associated to spinal morphine in a parturient submitted to Cesarean delivery under spinal anesthesia ${ }^{5}$.

One may consider in our case that neuraxial morphine has reached, by dispersion, opioid receptors of the hypothalamic region after approximately $3 \mathrm{~h} 30$ minutes. A thermoregulatory center disorder was then generated with the possible definition of a new hypothalamic temperature balance level, that is, the inter-threshold range as a whole was above this new upper temperature threshold generating excessive sweating with consequent heat loss to the environment and hypothermia. This response was only seen in regions above the umbilical line because more distal segments were still under residual sympathetic block.

This case has shown that interactions of anesthetic, surgical and environmental factors for the development of intraoperative thermal disorders may be even more complex. In addition to classic excessive heat loss mechanisms during neuraxial block, there may be direct disorders of hypothalamic temperature control centers, in our case associated to spinal morphine.

\section{REFERÊNCIAS - REFERENCES}

01. Sessler DI - Perioperative heat balance. Anesthesiology, 2000;92:578-596.

02. Sessler DI - Temperature Monitoring, em: Miller RD - Anesthesia, $5^{\text {th }}$ Ed, Philadelphia, PA: Churchill Livingstone, 2000; 1367-1389.

03. Frank SM, El-Rahmany HK, Cattaneo CG et al - Predictors of hypotermia during spinal anesthesia. Anesthesiology, 2000;92:1330-1334.
04. Sayyid SS, Jabbour DG, Baraka AS - Hypothermia and excessive sweating following intratecal morphine in a parturient undergoing cesarean delivery. Reg Anesth Pain Med, 2003;28: 140-143.

05. Wishaw K - Hypotermia associated with subarachnoid morphine. Anaesth Intensive Care, 1997;25:586.

06. De Witte J, Sessler DI - Perioperative shivering: physiology and pharmacology. Anesthesiology, 2002;96:467-484.

\section{RESUMEN}

Bicalho GP, Castro CHV, Cruvinel MGC, Bessa Júnior RC - Sudor Profuso e Hipotermia después de Administración de Morfina por Vía Subaracnoidea. Relato de Caso

JUSTIFICATIVA Y OBJETIVOS: La anestesia y cirugía con frecuencia causan alteraciones térmicas importantes. La hipotermia durante la anestesia es la alteración térmica más común en el perioperatorio. Este relato muestra un mecanismo no usual de alteración de la temperatura, en este caso, asociado con el empleo de morfina subaracnoidea. El objetivo de este relato fue describir el efecto raro.

RELATO DEL CASO: Paciente femenina, de 44 años, estado físico ASA I, sin enfermedades previas, fue admitida para realizar histerectomía abdominal por miomatosis uterina. Recibió raquianestesia con $20 \mathrm{mg}$ de de bupivacaína hiperbárica con $100 \mu \mathrm{g}$ de morfina. Durante el procedimiento no presentó ninguna alteración. En la sala de recuperación post-anestésica, 3 h30 minutos después de hecho el bloqueo, la paciente presento profusa sudoración en el tronco, que despega los electrodos y otros adhesivos, con leve somnolencia y disminución de la temperatura timpánica a $35,2^{\circ} \mathrm{C}$. En los 60 minutos siguientes mantuvo temperatura debajo de $36{ }^{\circ} \mathrm{C}$ pero a los 90 minutos la temperatura era de $36,2^{\circ} \mathrm{C}$ con remisión completa de los síntomas.

CONCLUSIONES: Aparte e los clásicos mecanismos de perdida de calor, pueden ocurrir perturbaciones directamente en los centros hipotalámicos de control de la temperatura corporal, que en este caso estuvo asociada a morfina subaracnoidea. 